\title{
ANALISIS DISIPLIN KERJA GURU DAN MOTIVASI BELAJAR TERHADAP PRESTASI BELAJAR SISWA PADA MATA PELAJARAN IPS KELAS VIII DI SMP N 8 PADANG
}

\author{
Stevani \\ Dosen Program Studi Pendidikan Ekonomi STKIP- PGRI Sumbar \\ Jl. Gunung Pangilun No.1, Padang Sumatera Barat \\ Email: stevani060390@gmail.com \\ submited: 2016.06.16 reviewed: 2016.06.22 accepted: 2016.06.24 \\ http://dx.doi.org/10.22202/economica.2015.v4.i1.625
}

\begin{abstract}
This study aims to look at the effect of labor discipline teachers on learning outcomes eighth grade students at SMP Negeri 8 Padang. influence the motivation to learn the results of class VIII student at SMPN 8 Padang influence teachers' work discipline and motivation to learn the results of class VIII student at SMPN 8 Padang. The study was descriptive associative. The study population was all students in grade 8 XIII SMP Negeri Padang enrolled in the academic year 2013/2014, totaling 224 students with a sample of 144 students. Results showed a positive and significant influence between the discipline teacher work on learning outcomes eighth grade students at SMP Negeri 8 Padang. The influence positf and significant correlation between motivation to learn the results of class VIII student at SMPN 8 Padang. The influence positf and significant correlation between teacher work discipline and motivation to learn the results of class VIII student at SMPN 8 Padang. Based on these results, improving student achievement can be achieved by increasing the teacher work kedosiplinan, thus increasing learning motivation and learning outcomes will be increased.
\end{abstract}

\begin{abstract}
Abstrak
Penelitian ini bertujuan untuk melihat pengaruh disiplin kerja guru terhadap hasil belajar siswa kelas VIII di SMP Negeri 8 Padang. pengaruh motivasi belajar terhadap hasil belajar siswa kelas VIII di SMP Negeri 8 Padang pengaruh disiplin kerja guru dan motivasi belajar terhadap hasil belajar siswa kelas VIII di SMP Negeri 8 Padang. Penelitian ini adalah deskriptif asosiatif. Populasi penelitian ini adalah seluruh siswa kelas XIII SMP Negeri 8 Padang yang terdaftar pada tahun ajaran 2013/2014, berjumlah 224 siswa dengan sampel 144 siswa. Hasil penelitian menunjukkan adanya pengaruh positif dan signifikan antara disiplin kerja guru terhadap hasil belajar siswa kelas VIII di SMP Negeri 8 Padang. Adanya pengaruh positf dan signifikan antara motivasi belajar terhadap hasil belajar siswa kelas VIII di SMP Negeri 8 Padang. Adanya pengaruh positf dan signifikan antara disiplin kerja guru dan motivasi belajar terhadap hasil belajar siswa kelas VIII di SMP Negeri 8 Padang. Berdasarkan hasil tersebut, meningkatkan prestasi belajar siswa dapat diupayakan dengan meningkatkan kedosiplinan kerja guru, sehingga motivasi belajar meningkat dan hasil belajar akan mengalami peningkatan.
\end{abstract}

Keywords: academic achievement, discipline of teachers, and motivationto learn 


\section{PENDAHULUAN}

Pendidikan merupakan salah satu kebutuhan manusia, karena dengan pendidikan manusia memperoleh pengetahuan, nilai, sikap serta keterampilan. Menyadari akan pentingnya pendidikan pemerintah Republik Indonesia telah menetapkan tujuan Pendidikan nasional. Tujuan dapat dicapai melalui pendidikan, dimana pendidikan adalah faktor penentu dalam meningkatkan kualitas manusia seperti yang diungkapkan dalam UndangUndang Republik Indonesia No. 20 Tahun 2003 tentang Sistem Pendidikan Nasional Pasal 3 mengenai fungsi dan tujuan pendidikan,bertujuan untuk berkembangnya potensi peserta didik agar menjadi manusia yang beriman dan bertakwa kepada Tuhan Yang Maha Esa, berakhlak mulia, sehat, berilmu, cakap, kreatif, mandiri, dan menjadi warga negara yang demokratis serta bertanggung jawab. Salah satu bentuk nyata hasil proses pembelajaran disekolah adalah tampak pada hasil belajar siswa pada setiap tingkat pendidikan. Hasil belajar yang baik mencerminkan bahwa siswa memiliki kemampuan yang lebih dibandingkan dengan siswa yang memiliki hasil belajar yang biasa saja

Sudjana (2005:11) hasil belajar adalah hasil yang di capai seseorang dalam penguasaan pengetahuaan dan keterampilan yang di kembangkan dalam pelajaran, lazimnya ditunjukan dengan tes angka nilai yang di berikan oleh guru. Banyak faktor yang mempengaruhi hasil belajar, dimana menurut Slameto (2013:54) secara global faktor-faktor yang mempengaruhi hasil belajar siswa yaitu: faktor internal (faktor dari dalam siswa) yang terdiri dari keadaan/kondisi jasmani dan rohani siswa, seperti kecerdasan, sikap, bakat, minat dan motivasi siswa. Faktor lainnya yang mempengaruhi hasil belajar siswa adalah faktor eksternal (faktor dari luar siswa) yakni: keadaan/kondisi lingkungan disekitar siswa, seperti faktor lingkungan sosial dan faktor lingkungan non sosial.

Salah satu faktor yang diduga mempengaruhi hasil belajar siswa adalah faktor dari guru itu sendiri, salah satunya yaitu disiplin kerja guru. Menurut Rivai, (2009:825), Disiplin Kerja adalah suatu alat yang digunakan para manajer untuk berkomunikasi dengan karyawan agar mereka bersedia untuk mengubah suatu perilaku serta sebagai suatu upaya untuk meningkatkan kesadaran dan kesediaan seseorang mentaati semua peraturan dan norma-norma sosial yang berlaku. Begitu juga dengan seorang guru, guru haruslah memiliki disiplin dalam bekerja sehingga terciptalah kepatuhan terhadap norma norma sehingga mematuhi peraturan dan menciptakan disiplin kerja yang berkualitas, sesungguhnya dengan disiplin yang berkualitas, diduga akan meningkatkan motivasi dan hasil belajar siswa.

Menurut Mc. Donald dalam Hamalik (2001: 158) "Motivasi adalah perubahan energi dalam diri (pribadi) seseorang yang ditandai dengan timbulnya perasaan dan reaksi untuk mencapai tujuan". Di dalam perumusan ini dapat kita lihat, bahwa ada tiga unsur yang saling berkaitan,Siswa yang memiliki motivasi tinggi dalam belajar memungkinkan akan memperoleh hasil belajar yang tinggi pula, artinya semakin tinggi motivasinya, semakin intens usaha dan upaya yang dilakukan, maka semakin tinggi pula hasil belajar yang diperolehnya.

Dengan penjabaran teori-teori ini, maka akan dianalisis bagaimana pengaruh disiplin kerja guru dan motivasi siswa terhadap hasil belajar IPS kelas VII di SMP Negeri 8 Padang semester genap tahun ajaran 2013/2014 


\section{Hasil Belajar}

Hasil belajar merupakan hasil yang diperoleh siswa setelah melakukan proses belajar. Belajar adalah proses perubahan perilaku berkat pengalaman dan latihan. Menurut Hamalik (2007:27), "belajar adalah modifikasi atau memperteguh kelakuan melalui pengalaman" atau "learning is defined as the modification or strengthening of behavior through experiencing". Menurut pengertian ini belajar merupakan suatu proses, suatu kegiatan dan bukan suatu hasil atau tujuan. Belajar bukan hanya mengingat, akan tetapi lebih luas dari itu, yakni mengalami.

Pandangan seseorang tentang belajar akan mempengaruhi cara belajarnya. Setiap orang mempunyai pandangan yang berbeda dengan belajar. Belajar merupakan usaha menuju ke arah perubahan tingkah laku yang lebih baik, sehingga terjadinya proses berfikir yang mampu menimbulkan pengalaman baru bagi pengajar dan pelajar. Jadi setelah mengikuti proses belajar maka diharapkan siswa memperoleh pengalaman baru dalam interaksi dengan lingkungan. Berdasarkan uraian di atas, dapat disimpulkan bahwa belajar adalah menghasilkan perubahan prilaku dalam diri seseorang. Perubahan terjadi sebagai hasil latihan, pengalaman dan pengembangan yang hasilnya dapat diamati secara langsung sehingga terjadi perubahan kearah yang lebih baik.

Hasil belajar merupakan hasil yang diperoleh siswa setelah melakukan proses belajar. Belajar adalah proses perubahan perilaku berkat pengalaman dan latihan. Menurut Hamalik (2007:27), "belajar adalah modifikasi atau memperteguh kelakuan melalui pengalaman" atau "learning is defined as the modification or strengthening of behavior through experiencing”. Menurut pengertian ini belajar merupakan suatu proses, suatu kegiatan dan bukan suatu hasil atau tujuan. Belajar bukan hanya mengingat, akan tetapi lebih luas dari itu, yakni mengalami.

Pandangan seseorang tentang belajar akan mempengaruhi cara belajarnya. Setiap orang mempunyai pandangan yang berbeda dengan belajar. Belajar merupakan usaha menuju ke arah perubahan tingkah laku yang lebih baik, sehingga terjadinya proses berfikir yang mampu menimbulkan pengalaman baru bagi pengajar dan pelajar. Jadi setelah mengikuti proses belajar maka diharapkan siswa memperoleh pengalaman baru dalam interaksi dengan lingkungan. Berdasarkan uraian di atas, dapat disimpulkan bahwa belajar adalah menghasilkan perubahan prilaku dalam diri seseorang. Perubahan terjadi sebagai hasil latihan, pengalaman dan pengembangan yang hasilnya dapat diamati secara langsung sehingga terjadi perubahan kearah yang lebih baik.

\section{Disiplin Kerja Guru}

Kata disiplin berasal dari bahasa Inggris yaitu diciple yang berarti penganut,pengikut, atau murid. Dalam bahasa Latin discipline diartikan latihan atau pendidikan, pengembangan tabiat, dan kesopanan. Sedangkan menurut Kamus Besar Bahasa Indonesia disiplin adalah ketaatan atau kepatuhan kepada peraturan Sinambela (2012) dalam Barnawi \& Arifin (2012: 110) mengatakan bahwa disiplin pada hakekatnya adalah kepatuhan pada aturan atau perintah yang ditetapkan oleh organisasi.sesuai dengan norma-norma atau aturan-aturan yang telah ditetapkan. Menurut Rivai, (2009:825), Disiplin Kerja adalah suatu alat yang digunakan para manajer untuk berkomunikasi dengan karyawan agar mereka bersedia untuk mengubah suatu perilaku serta sebagai suatu upaya untuk meningkatkan kesadaran dan kesediaan seseorang mentaati semua 
peraturan dan norma-norma sosial yang berlaku.

Guru yang berdisiplin perlu dikaitkan dengan kepatuhan dan ketaatan terhadap peraturan sekolah, seorang guru selain menjalankan tugasnya sebagai seorang pengajar, guru juga harus patuh dan tunduk terhadap peraturan yang tercantum dalam kode etik guru indonesia yang telah ditetapkan dalam suatu kongres oleh seluruh utusan cabang dan pengurus daerah PGRI dari seluruh penjuru tanah air. Kode etik guru indonesia berbunyi sebagai berikut (Arni Muhammad, dkk. 2005:31) guru indonesia menyadari bahwa, pendidikan adalah bidang pengabdian kepada Tuhan Yang Maha Esa. Bangsa dan Negara, serta kemanusiaan pada umumnya. Guru indonesia yang berjiwa pancasila dan setia kepada Undang-undang dasar Negara Republik Indonesia tahun 1945.

\section{Motivasi Belajar}

Menurut Sardiman (2001:71) "Motivasi berasal dari kata motif, diart.ikan sebagai daya upaya yang mendorong seseorang untuk melakukan sesuatu". Motif dapat dikatakan sebagai daya penggerak dari dalam dan dalam subjek untuk melakukan aktivitas-aktivitas tertentu demi mencapai suatu tujuan. Menurut Mc. Donald dalam Hamalik (2001: 158) "Motivasi adalah perubahan energi dalam diri (pribadi) seseorang yang ditandai dengan timbulnya perasaan dan reaksi untuk mencapai tujuan". Di dalam perumusan ini dapat kita lihat, bahwa ada beberapa unsur yang saling berkaitan, yaitu sebagai berikut :

1. Motivasi dimulai dari adanya perubahan energi dalam pribadi. perubahan-perubahan dalam motivasi timbul dari perubahanperubahan tertentu di dalam sistem neuropisiologis dalam organisme manusia, misalnya terjadi karena perubahan dalam sistem pencernaan maka timbul motif lapar.

2. Motivasi ditandai dengan timbulnya perasaan affective arousal. Mulamula merupakan ketegangan psikologis, lalu merupakan suasana emosi. Suasana emosi ini menimbulkan kelakuan yang bermotif. Perubahan ini mungkin bisa dan mungkin juga tidak, kita hanya dapat melihatnya dalam perbuatan. Seorang terlibat dalam suatu diskusi, karena dia merasa tertarik pada masalah yang akan dibicarakan maka suaranya akan timbul dan kata-katanya dengan lancar dan cepat akan keluar.

Dengan elemen di atas, maka dapat dikatakan bahwa motivasi sebagai sesuatu yang kompleks. Motivasi akan menyebabkan terjadinya suatu perubahan energi yang ada pada diri manusia, sehingga akan bergayut dengan persoalan gejala kejiwaan, perasaan, dan juga emosi, untuk kemudian bertindak atau melakukan sesuatu. Semua ini didorong karena adanya tujuan, kebutuhan atau keinginan.

\section{METODE PENELITIAN}

Penelitian ini digolongkan pada penelitian deskriptif dan asosiatif karena menerangkan suatu gejala dan peristiwa dari kejadian yang telah terjadi. Menurut Sugiyono (2012:56) penelitian deskriptif merupakan penelitian yang dilakukan untuk mengetahui nilai variabel mandiri, baik satu variabel atau lebih (independen) tanpa membuat perbandingan, menghubungkan dengan variabel lain. Selanjutnya Arikunto (2010:143) menjelaskan bahwa analisis asosiatif adalah bentuk analisis data penelitian untuk menguji ada tidaknya hubungan keberadaan variabel dari dua kelompok data atau lebih. Sebagaimana diketahui bahwa penelitian ini bertujuan 
untuk mengetahui pengeruh disiplin kerja guru dan motivasi belajar terhadap hasil belajar kelas VIII di smp n 8 padang pada mata pelajaran IPS.

Populasi dalam penelitian ini adalah sejumlah seluruh siswa kelas VIII SMP N 8 padang, yang terdiri dari 7 lokal yang berjumlah 224 siswa. Teknik pengambilan sampel ini adalah proposional random sampling. Dengan jumlah sampel 144 responden. Dengan nilai MID semester di peroleh dari data sekunder yaitu data yang ada di sekolah, seangkan pengaruh disiplin kerja guru dan motivasi belajar di ambil dari data primer yang diisi siswa.penyusunan angket atau kuesioner berpedoman kepada skala likert dengan beberapa alternative jawaban dengan diberi bobot penelitian positif dan negatif. Teknik analisis data yang digunakan adalah analisis deskriptif dan analisis induktif.

\section{HASIL PENELITIAN}

1. Disiplin Kerja Guru Berpengaruh Positif dan Signifikan Terhadap Hasil belajar IPS siswa kelas VIII SMPN 8 Padang

Berdasarkan analisis data dan pengujian hipotesis yang telah dilakukan diperoleh nilai $t_{\text {hitung }} 3,955>t_{\text {tabel }}$ sebesar 1,97705dengan nilai signifikan $0,000<a$ $=0,05$ berarti $\mathrm{H}_{\mathrm{a}}$ diterima dan $\mathrm{H}_{0}$ ditolak . Hal ini menunjukkan bahwa disiplin kerja guru berpengaruh secara signifikan terhadap hasil belajar IPS kelas VIII SMPN 8 Padang. Dengan demikian dapat disimpulkan semakin baik disiplin kerja gurumaka akan semakin baik pula hasil belajar yang diperoleh oleh siswa, begitu juga sebaliknya jika disiplin kerja guru yang diberikan kepada siswa kurang baik maka hasil belajar yang diperoleh siswa juga akan kurang baik atau kurang memuaskan.

Fanthoni

(2006:172), mengemukakan kedisiplinanmerupakan kesadaran dan kesediaan seseorang mentaati semua peraturan perusahaan dan norma-norma sosial berlaku, kesadaran adalah sikap seseorang yang secara sukarela mentaati semua peraturan dan sadar akan tugas dan tanggung jawabnya, sedangkan kesediaan adalah suatu sikap, tingkah laku dan perbuatan seseorang yang sesuai dengan peraturan perusahaan baik yang tertulis maupun tidak. Sementara itu, Menurut Bacal (2005:164), mendefinisikan disiplinadalah sebuah proses yang digunakan untuk menghadapi permasalahan kinerja, proses ini melibatkan manajer dalam mengidntifikasikan dan mengkomunikasikan masalah-masalah kinerja kepada para karyawan, bilapermasalahan kinerja tidak diperbaiki manajer juga terlibat dalam mengidentifikasikan,mengkomunikasikan dan menerapkankonsekuensinya, konsekuensi adalah apapun yang terjadi sebagai akibatlangsung suatu tindakan.

2. Motivasi Belajar Berpengaruh Positif dan Signifikan Terhadap Prestasi belajar IPS siswa kelas VIII SMPN 8 Padang

Penelitian ini bertujuan untuk mengetahui seberapa besar pengaruh motivasi belajar terhadap hasil belajar IPS kelas VIII SMPN 8 Padang. Berdasarkan analisis data dan pengujian hipotesis yang telah dilakukan diperoleh nilai $t_{\text {hitung }} 6,434>$ $t_{\text {tabel }}$ sebesar 1,97705 dengan nilai signifikan $0,000<a=0,05$ berarti $\mathrm{H}_{\mathrm{a}}$ diterima dan $\mathrm{H}_{0}$ ditolak. Hal ini menunjukkan bahwa motivasi belajar berpengaruh secara signifikan terhadap prestasi belajar IPS kelas VIII SMPN 8 Padang. Dengan demikian dapat disimpulkan semakin baik motivasi belajar maka akan semakin baik pula hasil belajar yang 
diperoleh oleh siswa, begitu juga sebaliknya jika motivasi belajar siswa kurang baik maka hasil belajar yang diperoleh siswa juga akan kurang baik atau kurang memuaskan.

Menurut Mc. Donald dalam Hamalik (2001: 158) "Motivasi adalah perubahan energi dalam diri (pribadi) seseorang yang ditandai dengan timbulnya perasaan dan reaksi untuk mencapai tujuan"M.Dalyono (200549) berpendapat bahwa "belajar adalah suatu usaha atau kegiatan yang bertujuan mengadakan perubahan di dalam diri seseorang mencakup perubahan tingkah laku, sikap, kebiasaan, ilmu pengetahuan, keterampilan, dan sebagainya." Menurut Djamarah (20011-159) "belajar adalah suatu aktivitas mental/psikis, yang berlangsung dalam interaksi aktif dengan lingkungan,keterampilan dan nilaisikap. Perubahan itu bersifat secara relative konstan dan berbekas".Dengan adanya motivasi belajar yang baik maka hasil belajar juga akan terlaksana dengan baik, begitu juga dengan meningkatnya motivasi belajar siswa, maka hasil belajar siswa juga akan mengalami peningkatan.

3. Disiplin Kerja Guru dan Motivasi Belajar Siswa Berpengaruh Positif dan Signifikan Secara Bersama-Sama Terhadap Hasil belajar IPS siswa kelas VIII SMPN 8 Padang

Berdasarkan pengujian hipotesis yang telah dilakukan diperoleh hasil bahwa disiplin kerja guru dan motivasi belajar berpengaruh positif dan signifikan terhadap hasil belajar IPS siswa kelas VIII SMPN 8 Padang. Hal ini dapat dilihat dari hasil pengolahan data dengan menggunakan program SPSS versi 16.0, menunjukkan bahwa nilai $F_{\text {hitung }} 112,822>F_{\text {tabel }} 2,67$ dan nilai signifikan $0,000<a=0,05$ yang berarti $\mathrm{H}_{0}$ ditolak dan $\mathrm{H}_{a}$ diterima. Dengan demikian dapat dikatakan bahwa disiplin kerja guru, pengelolaan proses belajar dan motivasi belajar siswa secara bersama-sama berpengaruh positif dan signifikan terhadap prestasi belajar IPS siswa kelas VIII SMPN 8 Padang, artinya semakin baik disiplin kerja guru, pengelolaan proses belajar dan motivasi belajar siswa maka prestasi belajar siswa juga akan semakin baik.

Oleh karena itu untuk meningkatkan prestasi belajar siswa, seorang guru harus memberikan contoh prilaku yang baik terhadap siswanya, baik dalam mematuhi peraturan yang ada maupun aturan yang disepakati bersama antara (guru dan siswa) Seorang guru harus mampu membangkitkan semangat siswa untuk memulai pembelajaran, seperti memberikan hadiah apabila seorang siswa mampu menjawab pertanyaan yang diberikan guru saat pembelajaran berlangsung. Dengan demikian penelitian ini sesuai dengan teori yang telah dikemukakan oleh para ahli.

\section{PENUTUP}

Hasil penelitian menunjukkan, (1) terdapat pengaruh positf dan signifikan antara disiplin kerja guru terhadap hasil belajar siswa kelas VIII di SMP Negeri 8 Padang. (2) terdapat pengaruh positf dan signifikan antara motivasi belajar terhadap hasil belajar siswa kelas VIII di SMP Negeri 8 Padang (3) terdapat pengaruh positf dan signifikan antara disiplin kerja guru dan motivasi belajar terhadap hasil belajar siswa kelas VIII di SMP Negeri 8 Padang. Berdasarkan hasil tersebut, 
meningkatkan prestasi belajar siswa dapat diupayakan dengan meningkatkan kedosiplinan kerja guru, sehingga motivasi belajar meningkat dan hasil belajar akan mengalami peningkatan.

\section{DAFTAR PUSTAKA}

10.22202/economica.2015.v4.i1.625

Arikunto, suharsimi.2010. Prosedur Penelitian. Rineka cipta. Jakarta

Dimyati \& Mudjiono. 2006. Belajar dan Pembelajaran. Rineka Cipta.Jakarta

Fanthoni, Abdurrahmat. (2006). Organisasi \& Manajemen Sumber Daya Manusia. PT.Rineka Cipta:Jakarta.

Handoko, T Hani. (2004). Manajemen.BPFE. Yogyakarta
Mengajar.Bumi Aksara. Jakarta

2009. Proses

Belajar

Rivai, Veithzal. (2009). Manajemen Sumber Daya Manusia untuk Perusahaan dari Teori ke Praktek. PT. Rajagrafindo Persada. Jakarta.

Sardiman.2011. Interaksi dan MotivasiBelajarMengajar:PT Raja Grafindo persada. Jakarta.

Sudjana,nana.2005.Dasar-Dasar Proses Belajar Mengajar: Sinar Baru Algesindo. Jakarta.

Sugiyono. 2011. Metode Penelitian

Pendidikan:Alfabeta.Bandung

Syah, muhibbin.2008. Psikologi Belajar, PT raja grafindo: Jakarta 